\title{
Financing Healthcare in Indonesia
}

\author{
Suryanto, V Plummer and M Boyle
}

\begin{abstract}
Introduction: There have been two major transitions for healthcare in Indonesia: the implementation of government decentralisation and universal health insurance. A universal public health insurance called Badan Penyelenggara Jaminan Sosial (BPJS) was launched in January 2014 and aims to cover all Indonesian people.
\end{abstract}

Objective: The objective of this paper is to discuss the funding of healthcare in Indonesia through a comparison with other South East Asian countries.

Methodology: A search for relevant literature was undertaken using electronic databases, Ovid Medline, ProQuest Central, and Scopus from their commencement date until December 2015. The grey literature from the Indonesian government, the WHO's and World Bank's website, has been included.

Results: There were nine articles from Ovid Medline, eight from ProQuest Central, and 12 from Scopus that met the criteria. Seventeen articles were duplicates leaving 12 articles to be reviewed. Nine documents have been identified from grey literature.
Discussion: Most people in Indonesia sought health services from the private sector and were out-ofpocket financially or did not receive the required care. The private sector delivered $62.1 \%$ of health services compared to $37.9 \%$ by the government. Despite some inappropriate use of previous health insurance, the BPJS is expected to have improved management and will cover all citizens by the end of 2019 .

Conclusion: Indonesia has undergone a series of changes to health system funding and health insurance. There are lessons that can be learnt from other countries, such as Thailand, Cambodia, and Vietnam, so that Indonesia can improve its health funding.

Abbreviations: BPJS - Badan Penyelenggara Jaminan Sosial.

Key words: financing; funding; health insurance; healthcare; health system; Indonesia.

\section{Suryanto}

PhD Candidate

School of Nursing and Midwifery

Monash University, Victoria, Australia.

School of Nursing

Brawijaya University, Malang, Jawa Timur, Indonesia.

\section{A/Professor Virginia Plummer}

School of Nursing and Midwifery

Monash University, Victoria, Australia.

\section{Dr Malcolm Boyle}

Department of Community Emergency Health and

Paramedic Practice

Monash University, Victoria, Australia.

\section{Correspondence:}

suryanto.s@monash.edu

suryanto.s@ub.ac.id

\section{Introduction}

The development and modernisation of the healthcare system in Indonesia is in a critical stage as the country is attempting to improve health outcomes for the poor as well as succeed in reaching the United Nations Millennium Development Goals. [1] There have been two major transitions for healthcare in Indonesia; the implementation of decentralisation of government authorities and universal health insurance coverage. [1] Decentralisation of government authorities was initiated in 2001 as a result of the fall of the Suharto regime [2] and this led to the increased authority of provincial governments to manage and organise health services for the community, including managing health funding. [3,4]

A new system of health insurance called Badan Penyelenggara Jaminan Sosial (BPJS) or universal health insurance coverage was launched on January 1, $2014[5,6]$ and it is 
estimated that it will cover all people in Indonesia by the end of 2019. [6] The achievement of $100 \%$ coverage in the next few years is remarkable given that only $63 \%$ of Indonesian people were covered by health insurance under governmental or private schemes in 2012 [7] and only 14\% in 2000. [8] The people covered by health insurance in 2000 were mostly civil servants and their family members who were covered by Asuransi Kesehatan (Askes) and employees in the formal sectors who were covered by Jaminan Sosial Tenaga Kerja (Jamsostek). [8]

In this article the funding of healthcare in Indonesia will be analysed and compared with other South East Asian countries. There are three major issues which will be covered; the development of health insurance, the implementation of the universal health coverage and finally the role of government and the private sector in healthcare funding.

\section{Methodology}

\section{Design}

A review of medical related electronic databases, Indonesian Government websites and international organisation publications to examine healthcare funding in Indonesia was undertaken.

\section{Process}

A search was undertaken using three electronic databases, Ovid Medline, ProQuest Central, and Scopus from their commencement date until the end of December 2015. The search strategy used the following keywords: 'financing', 'funding', 'health insurance,' 'healthcare', 'health system', and 'Indonesia'. The search used the keywords individually and in combination. The Indonesian government, the WHO's website, and World Bank's website were also searched for information about Indonesian health funding.
Articles and documents were included if they reported on the funding of healthcare in Indonesia, healthcare funding management in Indonesia, and health insurance in Indonesia either written in English or Bahasa Indonesia. Articles and documents were excluded if they were commentaries, letters to editors or if full-text was not available.

\section{Results}

There were 5,516 articles identified overall with 1,016 articles identified in the Ovid Medline, 1,378 in ProQuest Central, and 3,122 in Scopus. Further screening for relevance was undertaken based on the title and abstract. This resulted in 21 articles from Ovid Medline, 18 from ProQuest Central, and 31 from Scopus retrieved for further review. Those 70 articles were then reviewed based on inclusion and exclusion criteria. Based on the criteria, there were nine articles from Ovid Medline, eight from ProQuest Central, and 12 from Scopus with 17 of them duplicated leaving 12 articles to be reviewed. There were nine documents identified on the Indonesian government, the WHO, and World Bank's websites for inclusion in the review.

\section{Discussion}

The development of health insurance in Indonesia and other, similar countries

Indonesia has implemented one health insurance scheme specficially for the poor through the establishment of the BPJS program in early 2014. The poor and near poor are approximately $50 \%$ of the population and became the focus of the government response. This group is vulnerable to both economic and health shocks which can push the household into poverty. [1] In 2012, half of the population was covered by a government health insurance called Jamkesmas (50.4\%). [7] Details of the number of people covered by the different types of health insurance available in 2012 can be seen in Table 1.

Table 1: Coverage of Health Insurance in Indonesia in 2012

\begin{tabular}{|l|l|r|}
\hline TYPE OF HEALTH INSURANCE & MEMBERS & PERSONS \\
\hline Askes & Civil servants, pensioners & $17,274,520$ \\
\hline Military and police health insurance & Military and police officers & $2,200,000$ \\
\hline Jamkesmas (by national government) & Poor people & $76,400,000$ \\
\hline Jamsostek & Formal sector workers & $5,600,000$ \\
\hline Jamkesda (by regional government) & Poor people & $31,866,390$ \\
\hline Corporate insurance & Private members & $15,351,352$ \\
\hline Commercial health insurance & Private members & $2,856,539$ \\
\hline Total & & $151,548,981$ \\
\hline
\end{tabular}

Source: [7] Simmonds A, Hort K. Institutional Analysis of Indonesia's Proposed Road Map to Universal Health Coverage. Health Policy and Health Finance Knowledge Hub. 2013; 33: 1-13. 
During the regime of President Suharto, only civil servants, soldiers, and formal sector workers, such as State-Owned Enterprise workers, were covered by health insurance. [9] The health insurance for civil servants was called Askes and for formal sector workers was called Jamsostek. [8] These two health insurances were the most commonly used insurances and had the largest membership in Suharto's era. However, there were several changes to the health insurance program, which were initiated by the Indonesian government along with the fluctuations of the political situation and the development of Indonesia itself.

Askes was introduced in 1968 and had been compulsory for civil servants. A fixed monthly deduction of $2 \%$ of salaries had to be used as a premium the health insurance. [10] Askes not only covered the health insurance for civil servants, armed forces and their families, but also pensioners were covered for comprehensive health services provided by public health facilities. [10] Similar to Askes, Jamsostek was launched in 1992 and covered employees in formal sectors [9] with a higher premium than Askes, 3\% of their monthly salary for single employees and $6 \%$ of the monthly salary for married employees. [10]

Kartu Sehat, introduced in 1994 and ceased in 2004, was a health insurance program targeting poor households in order to reduce the inequality and access gaps for healthcare services. [11] In response to the Asian economic crisis and as a part of Jaring Pengaman Sosial (JPS) or the social safety net program in Indonesia, the insurance was reintroduced in 1998. $[9,11,12]$ The insurance provided health services, including outpatient and inpatient care, contraception, prenatal care, and delivery for poor people. [12] However, based on the study by Sparrow, [12] a large amount of the insurance went to richer quintile households, not the poor, since most of the targeted people were in rural areas with those poor rarely using the card due to a lack of access to health facilities. Another study showed that there was a low utilisation of the insurance due to the lack of public facilities. [11]

Asuransi Kesehatan Keluarga Miskin (Askeskin), was in place from 2004 to 2008, and was a program which was a substitute for the Kartu Sehat program. [13] Even though Askeskin had been successfully providing coverage for the poor, based on a socioeconomic survey in 2005 and 2006, the insurance was used by those other than the poor. [13] This problem was due to the 'open system' meaning eligible patients used self-identity as poor people, rather than identification by authorised persons or the health service, which lead to misuse of the system. [14]
Jaminan Kesehatan Masyarakat (Jamkesmas) is another health insurance for poor people which substituted Askeskin and commenced in 2008. [9] Compared to Askeskin, Jamkesmas had a higher coverage rate with 76 to 86 million Indonesians targeted at a total cost of 8.29 trillion rupiahs, about US\$703 million. [7,9] This expansion was due to increasing the coverage to include the near-poor. [15] The outcome was similar to other health insurance for the poor, in that Jamkesmas was under-utilised. [7] There were several factors influencing the underutilisation of the Jamkesmas including a lack of understanding of the program, the remote areas where the poor people lived meant that the services could not reach the targeted people, several other expenses for medicines were not covered by the insurance so the people still had to spend their own money for care, and finally and potentially most significantly, the stigma of perceiving and self-identifying as poor. [7]

Despite the wide coverage of the Jamkesmas national program, there were people who were not categorised as poor or near poor by the national criteria, thus several regional governments provided Jaminan Kesehatan Daerah (Jamkesda), which was managed by regional governments, to expand the coverage of Jamkesmas. [9] In spite of the underutilisation of the programs, Jamkesmas and Jamkesda had covered 76 million (32\% of total population) and 33 million (14\% of total population) people respectively by the end of 2011. [9] In order to enhance the Jamkesmas coverage for maternity services, in 2011, the Ministry of Health launched the Jaminan Persalinan (Jampersal) program which provided free maternal care including ante natal care, delivery service, postnatal care, neonatal care and contraception. [16]

While Indonesia started health insurance for the poor in 1994, Vietnam commenced a similar program in 1999, called the 'free card' program. [17] However, the program relied on local funding which led to the local government encountering several obstacles, especially where the poverty rate of the province was high, and this led to the low coverage of the population by this insurance. Therefore, in 2003, the new health insurance for the poor called Health Care Fund for the Poor (HCFP) was introduced. [17] In 2006, 20\% of the Vietnamese population, 14.5 million, were covered by the HCFP, but similar to Indonesia in regard to the misuse of the insurance, in Vietnam 3.5 million (40\%) people covered by the program were ineligible and 8.4 million eligible people were not covered by the program. [17] It is common that health services have a pro-rich bias. The experience in Indonesia and six other countries in Asia 
except Hong Kong, Malaysia, Sri Lanka, and Thailand was that the poor get far less advantages from services. [18] Forty-one percent of the richest in Indonesia benefited from health services while $7 \%$ and $5 \%$ of the poor benefited from both outpatient and inpatient services respectively. [18]

Compared to Thailand, Indonesia has also been slow to implement health insurance for the poor. In Thailand, the first health insurance for the poor, the Medical Welfare Scheme (MSW), was established in 1975 and was then followed by the establishment of health insurance for government and state enterprise employees called the Civil Servant Medical Benefit Scheme (CSMBS) in 1978. [19] On the other hand, the Indonesian government, initially, focused on health insurance for government employees instead of focusing on health insurance for the poor. The health insurance for government employees, Askes, was established in 1968, [10] while the first health insurance for the poor, Kartu Sehat, was established in 1994, [11] more than 20 years after.

\section{The implementation of BPJS}

In Indonesia the concept of BPJS is mutual assistance which is the program that will unify all health insurance schemes for civil servants, police, formal workers, and for the poor. [7] With respect to the premiums, based on the President's Regulation of the Republic of Indonesia (Peraturan Presiden), there are two categories of BPJS participants, Indonesian people without government support and Indonesian people with government support. [20] Based on this regulation, the government will give support to the poor for their health insurance premiums and others will self-fund or salary package via their employers.

Simmonds and Hort [7] argue that there are five major challenges in implementing the BPJS: the fragmented health financing system, decentralisation, demographic transition, high out-of-pocket spending, and low levels of spending on health by the central government. However, those challenges were met by the government through key regulations. The most current law, No. 111/2013, describes all aspects of the BPJS including types of participants, process of registration, premium fees, payment systems, service coverage and evaluation process. [20] However, as Indonesia is a lower-middle income country and has more than 250 million people with five-year target (end of 2019) to cover all citizens, it is a big challenge for the Indonesian government to implement universal health coverage.

Several lessons can be learnt from Thailand. In Thailand the universal health coverage called Universal Coverage Scheme (UCS) was implemented in April 2001 [19] and covered 75\% (47 million) of the population by 2003. [18,19] The government subsidy, from US\$ 1 billion in 2003 to US\$ 1.3-1.5 billion in 2004-2009, has influenced the successful implementation of the UCS in Thailand. [18] This success can be seen from the fact that the number of uninsured people had decreased sharply from $54.5 \%$ in 1996 to $29.8 \%$ in 2001. [19] Out-of-pocket payment is still dominant among lowmiddle income countries, [17] but the implementation of UCS in Thailand had reduced the out-of-pocket expenditure from 33\% in 2001 to $18 \%$ in 2008 while increasing the government subsidy from $50 \%$ to $67 \%$ of total health expenditure. [18]

\section{The role of Governments in healthcare funding}

The decentralisation of government authorities in Indonesia, which commenced in 2001, has significantly impacted the health system. Local governments have responsibility for planning, financing and distributing health services yet the central government has retained overall regulatory authority. [21] Every level of health office has their own roles. The provincial level health office main roles are training and coordination, the district-level health office has responsibility for delivering health services and allocating resources, while the sub-district level mainly focuses on providing basic health services in the Puskesmas, a type of community health centre. [1]

The implementation of a decentralised health system has made health financing more complicated as local governments could not implement all services arising from the mandatory universal health insurance from the central government. [1] Local governments had to apply a national health insurance scheme while also implementing decentralised health insurance and this was difficult to realise. Implementing both health insurance schemes was not only confusing for healthcare providers, but also for patients. As a result, almost half of the sick and injured in Indonesia sought health services from the private sector and were out-of-pocket, even though the government's principle, Alma Alta, is to provide universal access to primary care for all Indonesians. [1] A similar situation occurred in Cambodia where the country implemented health service decentralisation in 1994 and experienced similar obstacles to Indonesia. Lack of role clarity between the Provincial Health Departments and Operational Health District was one of the major problems resulting in poor integration. [22]

\section{Expenditure by sector and country type}

Since most Indonesians seek health services from the private sector it is not surprising that the majority of health 
expenditure in Indonesia is contributed by the private sector rather than the government. In 2011 the contribution was $62.1 \%$ by the private sector compared to $37.9 \%$ by the government [23] even though the government had increased funding of health as a proportion of total government expenditure, from $4.5 \%$ in 2000 to $6.2 \%$ in 2011. [23] However, this proportion is still below the average among South-East Asian countries, which was 7.3\% in 2000 and $8.7 \%$ in 2011 . The proportion of Indonesian health expenditure was $7.1 \%$ in 2000 and $8.1 \%$ in 2011. [23] Nevertheless, the health expenditure had been increased from 2.0\% of Gross Domestic Product (GDP) in 2000 to 2.9\% in 2011. Compared to other South-East Asian countries the proportion of health expenditure in Indonesia in 2011 was higher than Myanmar, 1.8\% of GDP, but lower than Thailand and Timor Leste, $4.1 \%$ and $4.6 \%$ respectively. [23] The detailed comparison of health expenditure in Indonesia and selected global societies can be seen in Table 2 . will focus on public health services including primary health services (Puskesmas) and public hospitals. [6] A study evaluating the impact of the universal health insurance in Thailand shows that the implementation of the insurance scheme may increase the use of district hospitals by $2.3 \%$ and decrease the use of provincial hospitals by $4.1 \%$. [18] This article may be potentially limited by the lack of accurate and current information about the Indonesian Government financial status and other literature about the financing of government authorities and the health system in general. There is also a lack of current documented government and health services funding from similar countries thereby making accurate and current comparisons difficult.

\section{Conclusion}

Many regulations have been issued in order to increase the health status of the Indonesian people, especially the poor, by rapid changes to health insurance during the last

Table 2: Comparison of Indonesian Health Expenditure and Other Countries in 2011

\begin{tabular}{|c|c|c|c|c|}
\hline CHARACTERISTICS & $\begin{array}{c}\text { TOTAL } \\
\text { EXPENDITURE } \\
\text { ON HEALTH AS } \\
\% \text { OF GDP }\end{array}$ & $\begin{array}{c}\text { GENERAL } \\
\text { GOVERNMENT } \\
\text { EXPENDITURE } \\
\text { ON HEALTH AS } \\
\% \text { OF TOTAL } \\
\text { HEALTH }\end{array}$ & $\begin{array}{c}\text { PRIVATE } \\
\text { EXPENDITURE } \\
\text { ON HEALTH AS } \\
\% \text { OF TOTAL } \\
\text { HEALTH } \\
\text { EXPENDITURE }\end{array}$ & $\begin{array}{c}\text { GENERAL } \\
\text { GOVERNMENT } \\
\text { EXPENDITURE } \\
\text { ON HEALTH AS } \\
\% \text { OF TOTAL } \\
\text { GOVERNMENT } \\
\text { EXPENDITURE }\end{array}$ \\
\hline Indonesia & 2.9 & 37.9 & 62.1 & 6.2 \\
\hline South-East Asian Countries (average) & 3.7 & 36.7 & 63.3 & 8.7 \\
\hline Lower-Middle Income Countries (average) & 4.4 & 36.6 & 63.4 & 8.1 \\
\hline Global (average) & 9.1 & 58.8 & 41.1 & 15.2 \\
\hline
\end{tabular}

Source: [23] World Health Organisation. World Health Statistics 2014. Available: <http://www.who.int/gho/publications/world_health_ statistics/2014/en/> (Accessed 14/05/15)

Even though the Gross National Income of Indonesia increased from US\$150,317 million in 2000 to US\$822,696 million in 2011, [24] health expenditure was still below 3\% of GDP in 2011. [23] In addition to this significantly below average government health expenditure, a large part of the government budget is for healthcare provider salaries. However, more than $67 \%$ of Puskesmas physicians were engaged in dual practice, in both the private and public sectors, [25] which may lead to an inefficient use of public funds for health. Even though Indonesians have utilised more private services than public, with the implementation of universal health coverage (BPJS) it is expected that there will be a shift from the private sector to public health services. [1] This is because the universal health insurance two decades. The current health insurance scheme (BPJS) is projected to provide access to healthcare services for all citizens in Indonesia by the end of 2019. It is believed that BPJS will be well implemented through the introduction of legislation. The most recent Indonesian government is likely to have new perspectives and ideas regarding health funding which could change policies, procedures and regulations about health insurance and this may influence both health services provision, insurance and funding arrangements, thereby improving outcomes for people seeking health services. Lessons can be learnt from other countries, such as Thailand, Cambodia, and Vietnam. 


\section{Competing Interests}

The authors declare they have no competing interests.

\section{References}

1. Rokx C, Schieber G, Harimurti P, Tandon A, Somanathan A. Health Financing in Indonesia: A Reform Road Map (accessed 26 Aug, 2013); 2009. Available from: https://openknowledge.worldbank.org/ handle/10986/2710

2. Kristiansen S, Santoso P. Surviving decentralisation? Impacts of regional autonomy on health service provision in Indonesia. Health Policy. 2006;77(3): 247-59.

3. Abdullah A, Hort K, Abidin AZ, Amin FM. How much does it cost to achieve coverage targets for primary healthcare services? A costing model from Aceh, Indonesia. Int J Health Plann Manag. 2012;27(3):226-45.

4. Heywood P, Choi Y. Health system performance at the district level in Indonesia after decentralization. BMC Int Health Hum Rights. 2010;10:12.

5. Lancet Editorial. Indonesia strides towards universal health care. Lancet 2014; 383(9911):2.

6. Aris J. Pelayanan Kesehatan Bagi PNS Saat Implementasi JKN dan BPJS Kesehatan 2014: PT ASKES 2013 (accessed April 6, 2014) . Available from: <http://hdl.handle.net/123456789/265>

7. Simmonds A, Hort K. Institutional Analysis of Indonesia's Proposed Road Map to Universal Health Coverage. Health Policy and Health Finance Knowledge Hub. 2013;33:1-13.

8. Erlyana E, Damrongplasit KK, Melnick G. Expanding health insurance to increase health care utilization: Will it have different effects in rural vs. urban areas? Health Policy. 2011;100(2-3):273-81.

9. Aspinall E. Health Care and Democratization in Indonesia. Democratization. 2014:1-21.

10. Hidayat $B$, Thabrany $H$, Dong $H$, Sauerborn $R$. The effects of mandatory health insurance on equity in access to outpatient care in Indonesia. Health Policy Plan 2004;19(5):322-35.

11. Johar M. The effect of a public health card program on the supply of health care. Soc Sci Med. 2010;70(10):1527-35.

12. Sparrow R. Targeting the poor in times of crisis: the Indonesian health card. Health Policy Plan. 2008;23(3):188-99.

13. Sparrow R, Suryahadi A, Widyanti W. Social health insurance for the poor:Targeting and impact of Indonesia's Askeskin programme. Soc Sci Med. 2013;96:264-71.

14. Idris F. An Error in Policy Level, Effect on Doctor and Patient? Indonesia Experience in 2005-2009. Japan Med Assoc J. 2010; 53(1):59-61.

15. Harimurti P, Pambudi E, Pigazzini A, Tandon A. The Nuts and Bolts of Jamkesmas: Indonesia's Government-Financed Health Coverage Program for the Poor and Near-Poor (accessed Aug 26, 2013). 2013. Available from: <https://openknowledge.worldbank.org/handle/ 10986/13304>

16. Kementerian Kesehatan Republik Indonesia. Profil Kesehatan Indonesia 2012 (accessed April 4, 2014). Available from: <http://www.depkes.go.id/index.php?vw=2\&pg=PublikasiDataDa nlnformasi>

17. Wagstaff A. Estimating health insurance impacts under unobserved heterogeneity: the case of Vietnam's health care fund for the poor. Health Econ. 2010;19(2):189-208.
18. Limwattananon $\mathrm{S}$, Tangcharoensathien $\mathrm{V}$, Tisayaticom $\mathrm{K}$ Boonyapaisarncharoen T, Prakongsai P. Why has the Universal Coverage Scheme in Thailand achieved a pro-poor public subsidy for health care? BMC Public Health. 2012;12 Suppl 1:S6.

19. Yiengprugsawan V, Carmichael G, Lim LY, Seubsman S, Sleigh A. Explanation of inequality in utilization of ambulatory care before and after universal health insurance in Thailand. Health Policy Plan. 2011;26(2):105-14.

20. Republik Indonesia. Peraturan Presiden Republik Indonesia Nomor 111 tahun 2013 (accessed April 14, 2014). Available from: $<$ http://www.hukor.depkes.go.id/?dokumen=global\&type=3\& th=2013>

21. Desai M, Rudge JW, Adisasmito W, Mounier-Jack S, Coker R. Critical interactions between Global Fund-supported programmes and health systems: a case study in Indonesia. Health Policy Plan. 2010;25:i43-7.

22. Men B, Grundy J, Cane J, Rasmey LC, An NS, Soeung SC, et al. Key issues relating to decentralization at the provincial level of health management in Cambodia. Int J Health Plann Manage. 2005; 20(1):3-19.

23. World Health Organisation. World Health Statistics 2014 (accessed May 14, 2015). Available from: <http://www.who.int/gho/ publications/world_health_statistics/2014/en/>

24. World Bank. International Debts Statistics 2013 (accessed August 26, 2013). Available from: <http://data.worldbank.org/sites/default/ files/ids-2013.pdf>

25. Rokx C, Giles J, Satriawan E, Marzoeki P, Harimurti P, Yavuz E. New Insight into the Provision of Health Services in Indonesia: A Health Workforce Study (accessed August 26, 2013). 2010. Available from: <https://openknowledge.worldbank.org/handle/10986/2434> 